\title{
Non-exclusive delegation to the European External Action Service
}

Citation for published version (APA):

Dijkstra, H. (2017). Non-exclusive delegation to the European External Action Service. In T. Delreux, \& J. Adriaensen (Eds.), The Principal Agent Model and the European Union (pp. 55-81). Palgrave Macmillan. https://doi.org/10.1007/978-3-319-55137-1_3

Document status and date:

Published: 18/10/2017

DOI:

10.1007/978-3-319-55137-1_3

Document Version:

Publisher's PDF, also known as Version of record

Document license:

Taverne

Please check the document version of this publication:

- A submitted manuscript is the version of the article upon submission and before peer-review. There can be important differences between the submitted version and the official published version of record.

People interested in the research are advised to contact the author for the final version of the publication, or visit the DOI to the publisher's website.

- The final author version and the galley proof are versions of the publication after peer review.

- The final published version features the final layout of the paper including the volume, issue and page numbers.

Link to publication

\footnotetext{
General rights rights.

- You may freely distribute the URL identifying the publication in the public portal. please follow below link for the End User Agreement:

www.umlib.nl/taverne-license

Take down policy

If you believe that this document breaches copyright please contact us at:

repository@maastrichtuniversity.nl

providing details and we will investigate your claim.
}

Copyright and moral rights for the publications made accessible in the public portal are retained by the authors and/or other copyright owners and it is a condition of accessing publications that users recognise and abide by the legal requirements associated with these

- Users may download and print one copy of any publication from the public portal for the purpose of private study or research.

- You may not further distribute the material or use it for any profit-making activity or commercial gain

If the publication is distributed under the terms of Article $25 \mathrm{fa}$ of the Dutch Copyright Act, indicated by the "Taverne" license above, 


\title{
Non-exclusive delegation to the European External Action Service
}

\author{
Hylke Dijkstra
}

\section{INTRODUCTION}

The principal-agent model is often used to explain the relations between the EU member states (the principals) and the EU institutions (the agents) (Pollack 1997, 2003; Kassim and Menon 2003; Dür and Elsig 2011; Delreux and Adriaensen this volume). The member states delegate functions to the institutions, because they expect that the EU institutions can better and/or cheaper carry out those functions than they themselves. The range of delegated functions is wide: from agenda management to chairing meetings, providing information, monitoring and enforcing compliance and representing the EU externally. The trouble with delegation is that the EU institutions typically have their own preferences and can use their information surplus and other resources to pursue those agendas. The member states thus have to invest in control mechanisms to keep the EU institutions honest.

Specialisation and a division of labour are at the heart of principalagent models. Member states 'outsource' functions to the EU institutions, because they no longer want to carry out those functions 'inhouse' or because they do not trust the other member states to carry out those functions (Tallberg 2002: 25). Member states thus benefit from delegation. At the same time, specialisation and the division of labour allow the EU institutions some influence. They can use their delegated

H. Dijkstra $(\square)$

Maastricht University, Maastricht, The Netherlands

(C) The Author(s) 2017

T. Delreux and J. Adriaensen (eds.), The Principal Agent Model and

the European Union, Palgrave Studies in European Union Politics,

DOI 10.1007/978-3-319-55137-1_3 
powers and resources at the expense of the membership. Precisely because member states have outsourced functions, they no longer have full control over them. This logic of a division of labour works well in most principal-agent studies of the European Commission, the European agencies, the European Court of Justice and the European Central Bank.

This chapter shows that there are also instances of non-exclusive delegation in the EU, i.e. member states delegate a function to the EU institutions, but (some of) the member states continue to also carry out this function themselves. ${ }^{1}$ The Common Foreign and Security Policy (CFSP) serves as a case. The member states have delegated to the High Representative and the European External Action Service (EEAS) the task and resources to represent the membership abroad, yet they continue to conduct their own foreign policies as well. ${ }^{2}$ The logic of specialisation and a division of labour is therefore at best unclear. To put it somewhat strongly, if the EEAS was about the outsourcing of foreign policy - for reasons of functionality and efficiency-we would expect the member states to close their foreign services and embassies. Naturally, this has not happened. The phenomenon of non-exclusive delegation is illustrated in Fig. 1.

Cases of non-exclusive delegation to EU agents present a challenge to the principal-agent model in multiple ways. First, they question the functional rationale behind the delegation process. If the member states did not delegate for reasons of specialisation and efficiency, then precisely what was the rationale for delegation? Second, they question whether the hierarchical relationship between the principal and agent still holds. If both the member states and the EEAS interact with external parties, we are likely to see competition for access. And rivalry is more about anarchy than about top-down hierarchy (Helwig this volume). Third, they question the existence and relevance of an information asymmetry. If the principals continue to entertain relations with external parties, then perhaps there is no agency problem that justifies the use of the model.

Rather than discarding the principal-agent model altogether, this chapter argues that cases of non-exclusive delegation give us an opportunity to revise the principal-agent model and to better delineate the boundaries of its domain of application. There is a real need to take the politics behind delegation more seriously and to account for the preferences and behaviour of individual principals. Generally speaking, the High Representative and EEAS provide a useful function for the member states in terms of external representation, but this does not mean that 


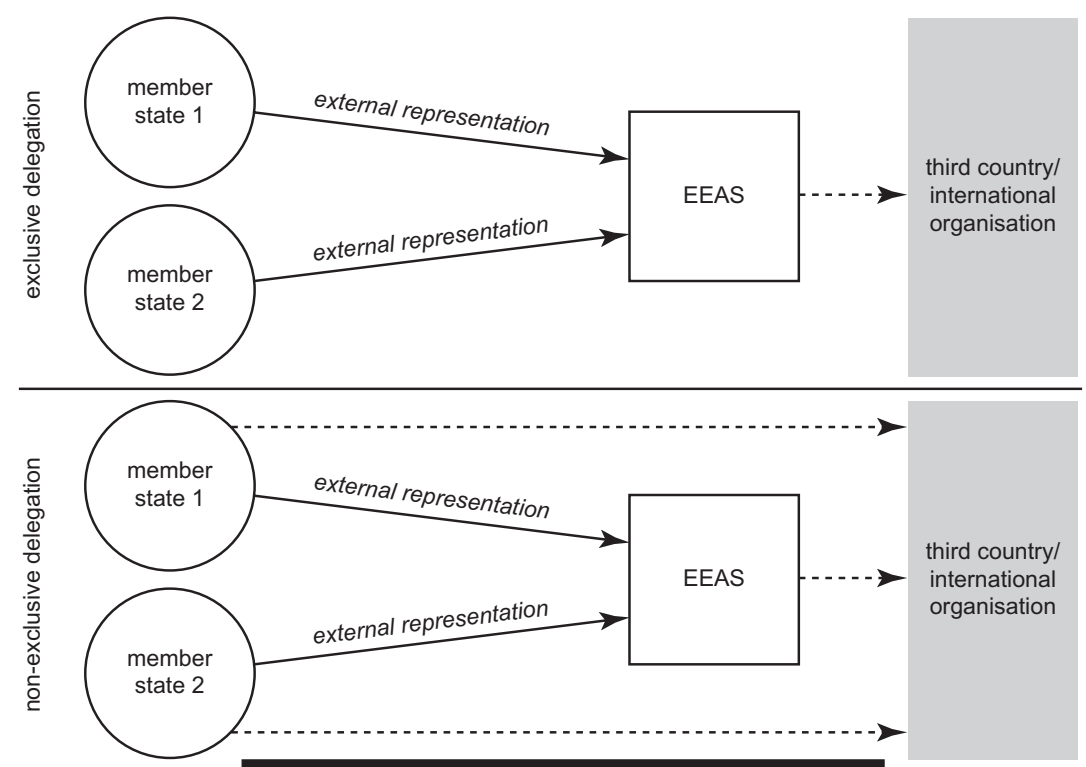

reasons and consequences of non-exclusive delegation

Fig. 1 Visualisation of the principal-agent relationship and non-exclusive delegation

they provide a useful function on every single issue for each of the member states. Post-delegation, there is equally a need to bring power back into the equation. Apart from micro-managing the EEAS through control mechanisms, strong member states may simply act through national rather than EU channels.

This chapter provides an illustration of the effects of non-exclusive delegation by looking at the development of the role of the EU Delegations (or 'EU embassies') across the world. ${ }^{3}$ These EU Delegations are an integral part of the EEAS (Council Decision 2010: article $1(4)$ ) and thus have a broad formal mandate in supporting the High Representative (ibid.: article 2(1)) including in the area of external representation (article 27(2) TEU). As a result, they often perform their functions in parallel to national embassies. This allows member states to act through both EU and national channels. Delegation is therefore non-exclusive and member states have an institutional choice. 
In line with this theory, the development of the EU Delegations after the Treaty of Lisbon has been uneven largely as a result of national interests. Moreover, principals and agents have tried to avoid outright hostility, but agreeing to a division of labour has been less than straightforward.

The emphasis is on cases of non-exclusive delegation, but there are equally instances of exclusive delegation in the CFSP. Many can be comfortably analysed through the principal-agent perspective. For example, when the High Representative chairs the Foreign Affairs Council, there is a principal-agent dynamic as the chairperson typically has procedural powers and informational advantages over the member states (Tallberg 2006). When the EEAS prepares military options, it likely has an information asymmetry as well over the member states as a result of its superior resources (Dijkstra 2013, 2016). When the EEAS mediates between Serbia and Kosovo, cases of hidden action may be observed (Bergmann and Niemann 2015). This chapter, however, focuses precisely on nonexclusive delegation to better understand the limits of the principalagent model. The overall point is therefore that we should be careful when using the principal-agent toolkit.

\section{Theoretical Puzzle: Non-exclusive delegation}

In the principal-agent model, the principal delegates a function to an agent, as the principal expects the agent to be able to better and/or cheaper carry out that function (Delreux and Adriaensen this volume). When municipality counsellors delegate waste disposal to garbage collection companies, it is because they do not want to get their own hands dirty. When patients see physicians, it is because they lack medical expertise. When shareholders appoint an executive board, it is because they do not have the time or the expertise to manage the company themselves. When the member states delegate the interpretation of EU laws to the European Court of Justice, it is because they do not trust each other in enforcing compliance. Outsourcing and a division of labour are therefore at the heart of the principal-agent model.

This cost-benefit logic is also strongly present in scholarly studies applying the principal-agent model to the case of the EU. Whether it concerns the Commission, Court of Justice, agencies, the rotating Presidency or the Council Secretariat, delegation is the result of a demand for efficiency and credibility, which the member states cannot or do not want to supply themselves (Pollack 1997, 2003; Beach 2005; 
Tallberg 2002, 2006; Franchino 2007; Dijkstra 2010). Not all delegation within the EU, however, follows a functional logic. The empowerment of the European Parliament, for example, can be better explained by a perceived need for legitimacy (Pollack 2003; Rittberger 2005). Yet even in the case of the European Parliament, there is some sort of a division of labour logic: the European Parliament has been delegated tasks, because EU legitimacy cannot be better supplied by another actor.

The principal-agent model is also increasingly used to understand the interaction between the member states and the newly created EEAS (Dijkstra 2013, 2016; Furness 2013; Kostanyan and Orbie 2013; Kostanyan 2014a, b; Henökl 2014). This is understandable since the hierarchical relationship is relatively straightforward: the member states are in charge of the CFSP and the EEAS helps them to formulate and implement foreign policy. ${ }^{4}$ The EEAS has been given a substantial budget and staff resources, but very few formal powers. Compared to the Commission and the Court of Justice, it is clearly not some sort of a trustee, which has been put at arm's length of the member states, to promote some form of collective 'European interest'. The EEAS, in many ways, therefore seems an ideal EU institution to study from the principal-agent perspective.

It is important, however, to recognise that the EEAS has been delegated several functions. And we need to distinguish between those different functions, as the principal-agent dynamics vary significantly. First, the EEAS facilitates foreign policy decision-making between the member states. It chairs the Foreign Affairs Council, Political and Security Committee and the most underlying working groups. It also provides member states with information and analysis to improve decision-making. Second, the EEAS plays a central role in crisis management and the Common Security and Defence Policy (CSDP). It drafts planning documents and it forms the liaison between the member states in Brussels and the CSDP operations across the globe. Third, the EEAS and its Delegations represent the EU towards external actors. This includes representation through ad hoc initiatives, diplomatic mediation, special envoys and the continuous political dialogue with external actors.

There is no doubt that the first two functions can be comfortably studied through the lenses of the principal-agent model. By having EEAS officials rather than diplomats from the six-monthly rotating Presidency chair the foreign affairs meetings (as was the case prior to the Lisbon Treaty), the member states benefit from continuity, impartiality and institutional 
memory. Yet at the same time, those permanent chairs can exploit their procedural and informational advantages (Beach 2005; Tallberg 2006; Puetter 2014). Through the delegation of CSDP functions, the member states benefit from specialisation, professionalisation and more efficient negotiations (Dijkstra 2013). When the time pressure is high, it is better to have one actor draft the military plan. And it is better if the military commander takes instructions from the EEAS than from 28 ambassadors with opposing views. But delegation in the CSDP empowers the EEAS and the member states need to keep a watchful eye (Dijkstra 2016).

This chapter focuses, however, on the third function of the EEAS: external representation. As will be discussed later in this chapter, it is precisely in this area that the use of the principal-agent model is most challenging. What distinguishes external representation from other functions is the involvement of external actors, such as third countries and international organisations. This allows for the possibility of non-exclusive delegation (see Fig. 1). In the case of exclusive delegation, the member states delegate external representation to the EEAS. The EEAS then exclusively interacts with an external party. We speak of non-exclusive delegation, however, when after the delegation of external representation to the EEAS, individual or groups of member states continue to interact with the same external actors on the same topics.

Instances of non-exclusive delegation raise several obvious challenges for the principal-agent model. These will be discussed in more detail below. To further specify the puzzle of non-exclusive delegation, however, it is first important to set out the benchmark: How does the principal-agent model explain the delegation of external representation to the EEAS? Once the traditional argument for delegation has been outlined, one can better appreciate the challenges of non-exclusive delegation.

So what does the traditional principal-agent model say? Two functional arguments are often made when studying EU external representation. First, the EU member states are relatively small states which have difficulty making their mark on global affairs. As a result, they have coordinated their national foreign policies since the 1970s to stand united. They have also delegated external representation to common EU agents, including the six-monthly rotating Presidency, the European Commission, the EEAS and even other member states. This allows them to speak with 'one voice'. Second, EU external representation allows for the pooling of resources. It is simply too expensive to keep a diplomatic 
network across the globe for most, if not all, member states. Rather than Estonia opening its own embassy in Windhoek, it is cheaper to act collectively through EU channels.

Both arguments-maximising diplomatic weight and minimising diplomatic costs-fall in the category of what an early observer of EU foreign policy once called the 'politics of scale' (Ginsberg 1989). As with its economic equivalent, the politics of scale logic is inherently functional: the member states delegate external representation to the EEAS to ensure that the EU speaks with 'one voice', makes a more significant impact globally and is cheaper in terms of organisation. This, in turn, benefits the membership as a whole. While acting through the EU structures might result in some costs-such as the need to coordinate internally and compromise, or the agency costs of the EEAS pursuing its own agendas-delegation ultimately takes place because the member states anticipate that the benefits of delegation outweigh the costs.

Importantly, the politics of scale logic expects only instances of exclusive delegation. If the member states indeed want to have a single agent speaking on behalf of the Union to have a single voice in world politics, there is no reason for them to also entertain bilateral relations with the same foreign counterparts. After all, multiple voices are not necessarily a choir. It would delude all the benefits of delegation. ${ }^{5}$ Similarly, if the member states support EU external representation, because they do not want to sustain a fully fledged global diplomatic network, it makes no sense for them to (keep) open their own bilateral embassies in parallel. In other words, the politics of scale approach fits neatly with the traditional principal-agent model. After all, the principal-agent model has many things to say about delegation, influence exerted by agents and the control mechanisms of member states.

If we are to follow the principal-agent model in its purest form, we would thus expect only cases of exclusive delegation. Instances of nonexclusive delegation would constitute a falsification of the theory. They present us therefore with a puzzle. ${ }^{6}$ While the member states have delegated external representation, they continue their own bilateral relations. In addition, the member states are often sitting at the same negotiations table when the EEAS interacts with foreign counterparts. In formal terms, one could perhaps make a distinction between speaking for the EU, 'Europe' or an individual member state (see for a discussion about the technicalities of representation in New York and Geneva: Laatikainen 
2015; Spence 2015: 227-230). Yet in reality, a division of labour quickly becomes blurred. The CFSP scope is global and all-encompassing. The EEAS entertains a political dialogue with almost every actor on almost every topic. Furthermore, foreign counterparts are unlikely to make the relevant distinctions between 'the EU' and 'Europe'.

The problem of non-exclusive delegation in foreign policy is decades old. A vivid example which pre-dates the Lisbon Treaty concerns EU representation during the Dayton Conference of 1995. For this important summit about peace in former Yugoslavia, the member states appointed Carl Bildt as their representative. Bildt had previously been the EU's envoy to former Yugoslavia and had diplomatic standing as the former Prime Minister of Sweden. On behalf of the EU, he even became one of the three co-chairmen of Dayton. Yet in spite of such clear case of delegation, it did not prevent France and the United Kingdom (and Germany) from sitting at the very same Dayton negotiating table on behalf of themselves. Lead negotiator Richard Holbrooke (1998: 242), one of the foreign counterparts, writes about this episode that:

Pauline Neville-Jones and Jacques Blot told us privately that Bildt could not speak for their governments on certain issues. This made a mockery of both the theory and the practice of having a E.U. representative as co-chairman, and raised other questions. Whom did Bildt speak for? And when? What, in fact, was his authority? Did he represent only the E.U. countries that were not there? [...] What troubled us most was the hypocrisy of the European Union in giving a distinguished former Prime Minister such a grandiose title, then undermining and hamstringing him from the outset.

While some would probably wish to forget about this historical event, the reality is that even under the Lisbon Treaty the situation often remains the same. One only needs to point at the marginal role of the EU institutions in the G7/G20 formations. The authority of EU agents gets undermined continuously by member states interacting with external actors on their own behalf. In fact, only in very few instances of serious external representation, the High Representative and the EEAS have the complete authority to entertain exclusive relations and to speak about CFSP matters on behalf of the EU and its member states. This is, for example, very different from the common commercial policy, where the EU holds an exclusive competence. 
It is important to study cases of non-exclusive delegation in EU external representation as they present a challenge to the principal-agent model and its functional logic. It allows us to revise and improve the model and identify the boundaries of its domain of application. The puzzle of non-exclusive delegation provides three challenges to the principal-agent model. First, if the member states do not delegate the task of EU external representation to the EEAS for reasons such as specialisation and the politics of scale (Delreux and Adriaensen this volume), then precisely what was the reason for delegation? The politics of scale argument is about speaking with 'one voice' by means of having a single EU agent for external representation. If the member states, however, continue their bilateral relations or make clear to external parties that the EEAS does not speak for them, then why would they spend significant resources on the EEAS in the first place?

Second, cases of non-exclusive delegation challenge the hierarchical relationship between the principals and the agents. With two or more captains on the ship, we are likely to see a degree of rivalry between the member states and the EEAS. The time and interest of foreign counterparts is, for example, limited. The member states and the EEAS thus need to compete for access. Similarly, they will likely be in a struggle for visibility in the relevant news media. To a certain extent, we would thus expect a scramble for access and visibility. Such rivalry is more likely to be anarchical rather than hierarchical. This challenges the most fundamental aspect of the principal-agent model (Delreux and Adriaensen this volume). It really makes us wonder whether we can still talk about principals and agents.

Third, if relations between the EEAS and external parties are not exclusive, it significantly affects the potential for hidden information and hidden action. After all, the member states may acquire the same sort of information from foreign counterparts. This goes in particular for the large EU member states, which are likely to have better resources, access and information than the EU Delegations. Furthermore, if the member states have their own embassies in foreign countries, they can appoint staff to keep a watchful eye on the actions of the EEAS and its local Delegations. Such a control mechanism further reduces the possibilities for information asymmetry. It thus reduces the potential agency problem. And if there is no agency problem, or a small one at best, one needs to wonder what the added value is of the principal-agent model to understanding the relations between the member states and the EEAS. ${ }^{7}$ 


\section{Empirical Analysis: EU Delegations AND EXTERNAL REPRESENTATION}

This chapter has, so far, raised the possible problem of non-exclusive delegation in EU external representation. To sustain that this problem is more than an intellectual exercise, it is important to provide empirical evidence. This section discusses the role of the EU Delegations after the Treaty of Lisbon of 2009. The approximately 140 EU Delegations have been at the forefront of EU external representation. Their ambiguous and largely undefined role and the variation across all these EU Delegations make them excellent test cases to analyse non-exclusive delegation. This section builds on academic research carried out by various scholars. The purpose is, first, to show that the problem of non-exclusive delegation is real and should be part of the principal-agent model. The second aim is to provide empirical input for the theoretical argument presented below.

The starting point for the empirical analysis is to provide some background on the historical development of the EU Delegations. Already from the start of the European integration project, there was a need to provide permanent liaison with external actors. Prior to the Treaty of Rome of 1957, an Office of the European Coal and Steel Community had already been opened in Washington, DC in 1954. Information Offices were furthermore opened in potential candidate countries, such as the United Kingdom. During the 1960s, Offices were opened in developing countries, a practice that increased dramatically following decolonisation and the negotiation of the Lomé agreements. By the late 1970s, there were Delegations in most OECD countries, developing countries and various international organisations (Bruter 1999; Spence 2004; European Commission 2004; Carta 2012; Drieskens 2012; Austermann 2014). ${ }^{8}$ Delegations in major centres like Beijing and Moscow were not opened until, respectively, 1988 and 1991.

These Delegations were Commission Delegations. As part of the work of the Commission, they implemented external relations policies. They were composed of Commission staff and local officers. They reported to the Commission. Such atypical diplomatic representation caused naturally some problems with protocol and accreditation. The Commission staff member appointed as Head of Delegation could, for example, not be called an 'ambassador' (Bruter 1999: 190). And there were serious discussions how the Commission Delegations joined international 
negotiations. Would the Commission officials join the negotiation team of the rotating EU Presidency or would they speak on their own behalf? Finally, in a world of sovereign states, when speaking slots or the chairs in the conference room were allocated, the Commission officials typically did not get first choice (Spence 2015: 235-236). Diplomatic life was by no means easy for these Commission Delegations.

Any yet there was also considerable clarity. Commission Delegations were representing the Commission and not the EU. They could pursue Commission policy. Furthermore, the Commission Delegations concerned themselves mostly with the competences of the Commission. This meant trade and development policy. As such, there was little friction with the embassies of the member states. Finally, while the lack of de jure recognition undermined the position of the Commission, Commission Delegations typically did not have problems establishing de facto recognition on topics where they had competence (Jupille and Caporaso 1998). The title of the Head of Delegation instead of ambassador was less of a problem in practice than in theory.

Much of this has changed following the Treaty of Lisbon. While Commission Delegations in many countries already had a coordination role and engaged in political dialogue, the rebranding into EU Delegations meant four things. First, they represent the full EU including its member states. Second, they have an explicit political and diplomatic role, as they service the EEAS. This means diplomatic outreach and information gathering. Third, they were upgraded in terms of resources. For the new tasks, the EU Delegations received reinforcements. Fourth, internal EU coordination has become a serious and Delegation-run affair in many third countries. While Commission Delegations previously could make their offices available and serve the coffee, Delegation officials now actually chair those meetings and set the agendas.

In other words, the development from Commission Delegations to EU Delegations was not a cosmetic reorganisation. It has really turned EU Delegations into relevant diplomatic actors. What also testifies to this is the open-ended mandate that they have received. In legal terms, they are an integral part of the EEAS (Council Decision 2010: article l(4)). The EEAS, in turn, is tasked to support the High Representative (ibid.: article 2(1)). And the High Representative represents 'the Union for matters relating to the common foreign and security policy' (article 27(2) TEU). In other words, the EU Delegations have the derived 
authority to represent the EU in third countries and international organisations. Given that the CFSP-through its policies and statements-covers nearly every imaginable topic about all the corners of the world, this gives EU Delegations a broad mandate indeed.

Few member states have downgraded their diplomatic network in spite of the delegation of additional authority to the EU Delegations. Several have reduced their diplomatic service, notably the United Kingdom, but this has been the result of the economic crisis and budget cuts. Few have considered the actual outsourcing of foreign policy (Balfour and Raik 2013a: 37; 2013b: 6-7). There are some examples of increased intra-European cooperation. The Nordic houses, which colocate Nordic embassies in some 30 places around the world (Ministers of Foreign Affairs of Denmark, Finland, Iceland, Norway and Sweden 2014; Balfour and Raik 2013b), are frequently mentioned. The 'laptop diplomat' holding office in another embassy is an increasing phenomenon (Rena 2013: 72). Consular cooperation is extensive in many countries (UK House of Lords 2013: paragraphs 47-49; Balfour and Raik 2013b). Various member states closed their embassies in Syria in 2011 in protest to the escalating civil war, only to relocate diplomats to the local EU Delegation. Such developments, significant as they may be, also stand separate from the establishment of EU Delegations.

Upgrading EU Delegations has therefore resulted in an indisputable case of non-exclusive delegation. In various third countries and most international organisations, the member states are represented via national and EU channels. ${ }^{9}$ The key empirical question is how does this work and can we identify relevant principal-agent dilemmas? The three questions, in this respect, are: Why the member states delegated in the first place, if not for reasons of efficiency and politics of scale? To what extent the parallel presence of national and EU diplomatic channels challenges the hierarchical nature underpinning the relation between principals and agents? And whether we can still speak of an information asymmetry and a real agency problem?

\subsection{The Politics of Delegation}

One of the key observations is the variation in how Commission Delegations were upgraded into EU Delegations. Austermann (2014) talks of 'different speeds' (see also chapters in Spence and Batora 2015). Not all Commission Delegations were turned into fully functioning 
EU Delegations overnight. Indeed, the EEAS took its time to establish the EU Delegations in consultation with the member states. Such variation allows us to examine the rationale for delegation, as it allows for a large- $\mathrm{N}$ comparison. To generalise slightly, the establishment of EU Delegations has been most successful in countries where member states have few interests. Balfour and Raik (2013a: 44) note that the EU Delegations' representative role 'has been relatively easy to establish in less important and peripheral locations where member states have fewer political interests at play ... The easiest cases are locations where one's own country has no representation'. Washington, DC, Beijing, New Delhi, Moscow, Cairo and Tokyo are considered challenging locations for EU Delegations (ibid.: 46; Austermann 2014).

An argument could therefore be made that non-exclusive delegation only concerns a limited number of high-profile instances of foreign policy. And yet, even in less important countries, it is not necessarily about outsourcing and exclusive delegation. Balfour and Raik (2013a: 38), for example, underline the absence of the efficiency rationale when stating that:

Rather than having, say, 15 embassies of EU member states in Baku or 7 in Montevideo, in addition to a delegation of the EU that spends much of its time and resources on coordinating among the member states, would it not make sense to have just one large EU [D]elegation representing the whole Union and limit national missions to a minimum? [...] This is not how most member states' foreign services see the relationship between national and EU diplomacy in the foreseeable future.

To avoid blatant rivalry in third countries on the ground, much of the discourse has been on the complementary services that the EU Delegations have on offer. Balfour and Raik (2013a: 33) note that 'the EEAS has been careful to underline that it does not aim to replace the ministries of foreign affairs [...] many member states have been recalling that it is not the purpose of the EEAS to make national diplomacies redundant'. Complementary services include systematic intra-EU coordination meetings and limited diplomatic reporting to the EU institutions, including the Council institutions, in Brussels. In other words, the uneasiness about the new relationship between the EU Delegations and national embassies has resulted in a situation where the EU Delegations are holding back and, at the same time, have not fully been resourced to fully carry out their new functions. 


\subsection{Challenging the Hierarchy}

It is worth examining the difficult cases a bit further, as it is in those cases that EU foreign policy really matters. To what extent do we see rivalry between EU Delegations and embassies and can we still speak of a hierarchical relationship?

Maurer (2015: 276) writes about Washington, DC as 'the most important diplomatic representation for many countries' where '[g]aining attention of the US administration [...] makes for a constant diplomatic "beauty contest"'. While the United States is perhaps among the third countries supportive of having EU agents in foreign policy, as it easier to deal with one EU agent than with all the member states bilaterally, this is not how the member states have felt about it. Maurer (2015: 281 ) indeed notes that member states have been suspicious of the EU Delegation playing a role in political and security areas. Instead, they have preferred the EU Delegation to play a role in intra-EU coordination at the service of the member states. Such role was also favoured by the first Head of the EU Delegation appointed in 2010. Other typical roles are public diplomacy about the EU as well as the negotiation of the Transatlantic Trade and Investment Partnership. As Maurer (2015: 281) states ' $\mathrm{t}]$ he $[\mathrm{D}$ ] elegation did not simply become an additional embassy'.

The EU Delegation in Beijing has hardly managed to do better in terms of capitalising on the Lisbon reforms. Austermann (2012: 101) writes that ' $[\mathrm{d}]$ espite the clearly upgraded political role, the EU Delegation cannot do away with $[\ldots]$ the diverging interests of member states. This makes it difficult to speak always with one voice in Beijing'. Member states were pleased to have the Head of Delegation speak about human rights, such as in the case of the detention of $\mathrm{Ai}$ Weiwei, but refused to allow him to speak on behalf of the whole EU (ibid.: Austermann 2015: 301). 'When it comes to the external display', Austermann (2015: 298) writes, the profile of the EU Delegation in Beijing is 'relatively humble'.

In addition to bilateral relations with third countries, EU Delegations play a significant role in several international organisations. The EU Delegation to the United Nations (UN) in New York is one of the most important in this respect. This has become something of a powerhouse as a result of the merger of different functions. The Commission Delegation had already a significant presence due to its development portfolio. The EU Council Liaison Office, organising 1000+ annual intra-EU coordination meetings at its premises, was already a pivotal 
player/venue prior to Lisbon. The EU Delegation also took gradually charge of the substantial role of the rotating EU Presidency, which previously represented the EU in many UN negotiations with the exception of the Security Council. The combination of these functions has resulted in a strong EU agent in terms of external representation.

The role of the EU Delegation in New York has been analysed extensively elsewhere (Drieskens 2012; Laatikainen 2015), but it is still worth making some points. First, since the EU is not a full member of the UN, a considerable diplomatic effort had to be made to convince the other UN member states that the EU Delegation (rather than the rotating Presidency) could actually speak and participate in the negotiations. Furthermore, the United Kingdom started a philosophical debate about what external representation meant leading to various detailed guidelines (Laatikainen 2015: 198-204). Since the EU Delegation cannot provide an explanation of vote in the UN (as it does not vote) and lacks other formal powers, it still needs to rely on the member states under a burden-sharing arrangement (ibid.: 205). There are also other burden-sharing or re-delegation arrangements due to the EU Delegation's lack of resources. In short, delegation is heavily compromised.

\subsection{Hidden Information and Hidden Action}

Finally, to what extent can the EU Delegations accumulate an information surplus over the member states, which the EEAS can use to exert influence? This question goes to the heart of the principal-agent model, which assumes that specialisation leads to information asymmetries. As I noted elsewhere (Dijkstra 2015, 2016; also Adriaensen 2016), it is useful to pay attention to the relative administrative capacity of the member states in this respect. Strong states might dedicate significant staff resources to certain issues to avoid dependence on the information of EU agents. When assessing the administrative capacity of the member states in some important third countries, it becomes quickly obvious that the EU Delegations are outnumbered. Table 1, for instance, shows that the EU Delegation in Washington, DC does not rival some of the larger European embassies in terms of staff resources. The picture is similar in other capitals, such as Beijing (Austermann 2014: Table 3.2).

Naturally, the number of diplomats is a crude indicator when considering information asymmetries. National diplomats are mostly in Washington, DC on national business rather than to control what the EU Delegation 
Table 1 Number of accredited diplomats of key member states and the EU Delegation in Washington, DC

\begin{tabular}{llll}
\hline & Washington, DC (1998) & Washington, DC (2012) & Difference \\
\hline Germany & 86 & 136 & $+50(+58 \%)$ \\
United Kingdom & 74 & 116 & $+42(+57 \%)$ \\
France & 62 & 56 & $-6(-10 \%)$ \\
Italy & 29 & 41 & $+12(+41 \%)$ \\
Spain & 39 & 35 & $-4(-10 \%)$ \\
EU Delegation & 22 & 33 & $+11(+50 \%)$ \\
The Netherlands & 36 & 32 & $-4(-11 \%)$ \\
\hline
\end{tabular}

Sources Bruter (1999) and Maurer (2015)

is doing. Furthermore, the size of the EU Delegation is still considerably bigger than the embassies of many of the smaller member states. That having been said, it is unlikely that the EU Delegation will easily gather more information about the host country on the large majority of policy dossiers than some of the much more sizeable national embassies. Indeed, the problem may be the other way around: that the key member states do not share enough information for the EEAS and the EU Delegations to do their work properly. Consequentially, there is a real question about the present of an informational asymmetry that allows for EEAS agency.

This empirical section has pointed at the presence of non-exclusive delegation in the field of EU external representation. A closer empirical look at the EU Delegations shows three things. First, there is significant variation in the development of EU Delegations. Some have become EU agents in third countries; others have a more limited role. Second, while rivalry is never far away, most EU Delegations have been sensitive to the member states in order to avoid open conflict. Some sense of hierarchy is thus present, particularly in some of the key capitals, even if informal and not absolute. Third, in key capitals it is difficult to see how EU Delegations can develop significant information surpluses as long as they remain relatively weak in terms of administrative capacity.

\section{Theoretical Argument}

How can we make sense of the puzzle of non-exclusive delegation in EU external representation? The answer is that while many principal-agent scholars focus traditionally on the collectivity of member states, they 
should pay more attention to the individual member states and their behaviour (Gutner 2005; Thompson 2007; Sobol 2016). Individual member states make trade-offs in Treaty negotiations, face incomplete contracting and uncertainty and engage in bureaucratic politics. They may support some parts of the EEAS and its Delegations, but not necessarily all. The level of conflict between the member states is often conveniently written out of principal-agent equations by assuming a so-called collective principal. Yet cases of non-exclusive delegation show that this approach is hardly sustainable.

To understand non-exclusive delegation, we need to make a distinction between the multiple principals and the collective principal. The multiple principals perspective argues that all member states entertain bilateral relations with the agent. The collective principal perspective argues that the member states collectively entertain relations with the agent. It requires them to first solve their own differences before reaching out to the agent. The collective principal perspective is overwhelmingly used in the study of the EU and international organisations (Nielson and Tierney 2003; Lynn et al. 2006; Hawkins et al. 2006; Moravcsik 1998). After all, it follows the formal rules. The member states decide collectively whether to delegate. Such decisions are often subject to consensus. Delegation is therefore implicitly assumed to be a positive-sum game with benefits for all member states.

If delegation is, however, a positive-sum game, there is no reason to expect non-exclusive delegation. If it is beneficial for all member states, why would member states then continue their own bilateral relations with external parties? The answer is that delegation is not necessarily a positive-sum game. The EEAS and its Delegations provide a useful illustration. As a result of the problem of incomplete contracting, delegation plays on multiple levels (Treaty level, Council Decision level, local EU Delegation level). Not everything can be decided at Treaty level, because this would make the contract impossibly complex. One can therefore not bring delegation to the EEAS and its Delegations back to a oneshot decision by the collectivity of member states in the Lisbon Treaty. Delegation decisions are taken continuously.

First, it is important to underline that there have been trade-offs between the principals when negotiating the Lisbon Treaty. The Lisbon Treaty was clearly not only about the CFSP, but about a range of dossiers. Some were important for some individual principals; others were important for others. The whole package was digestible for all member 
states acting together as a collective principal. The CFSP has traditionally been part of the trade-off in such treaty negotiations (Nuttall 2000). Elements of political union, including foreign policy, have been important for Germany, in particular, to make the EU more than a unidirectional transfer of money. At the same time, it is fair to say that several member states would not have signed up to the EEAS if it was not part of a broader package deal in the Lisbon Treaty. As such, the process of delegation, including the delegation of CFSP tasks to the EEAS, is not always a positive-sum game. Delegation may result in negative pay-offs for principals, but they accept this loss as they are compensated elsewhere. The result is that those principals will be actively working against the EU agent post-delegation.

The trouble with Treaty negotiations is, secondly, that they result in incomplete contracting. The Lisbon Treaty was, for example, hardly precise on the CFSP agents, namely the EEAS and its Delegations. The details thus needed to be filled in at a later stage. This happened through a Council Decision in 2010. The negotiations dynamics here were different. While the Lisbon Treaty established the EEAS, there was still extensive room for discussion on its scope, resources, control mechanisms, etc. Since the Council Decision was negotiated on its own merits and was not part of a package deal, and since agreement required consensus within the collective principal, it is not surprising that the result was a lowest common denominator deal. That having been said, the basic idea that the EU Delegations around the world would get some external representation mandate was acceptable even for the most sceptical principals (short of the fact that it was in the Lisbon Treaty).

The third level of negotiations was what would happen with the individual EU Delegations on the ground in third countries and international organisations. In some cases, there were formal negotiations about the division of labour (Spence 2015; Laatikainen 2015). In other cases, there were no negotiations but informal developments. The overall point is, however, that the individual principals held, once again, different preferences. While Germany was perhaps supportive of the whole idea of EU Delegations in the Lisbon Treaty and the Council Decision, it may have been a bit more sceptical of delegation to the EU Delegations in Washington, DC and Beijing. Similarly, Belgium, while being a proponent of the EEAS, has not closed its own embassy in Kinshasa.

The differentiation between the Lisbon Treaty (should we have EU Delegations?), the Council Decision (what should EU Delegations do?) 
and the developments on the ground (what should the EU Delegation in Moscow do?), which is a logical result of the impossibility of complete contracting, clearly allows for instances of non-exclusive delegation. ${ }^{10}$ Even if all the member states in the collective principal find it useful to have an EEAS and its Delegations represent the Union abroad, individual principals may still not support the work of a specific EU Delegation in a specific country. Delegation to the EU Delegations thus gets continuously challenged by individual principals, which inter alia continue to pursue their own bilateral policies. Thompson (2007: 9-11) calls this 'principal problems' at the expense of 'innocent agents'. Similarly, recent literature about international organisations argues that states pursue unilateral influence through international organisations (Thacker 1999; Stone 2004, 2008, 2011; Oatley and Yackee 2004; Dreher and Jensen 2007).

Member states therefore may support the overall act of delegation to an EU agent, but not all the detailed instances of delegation. In such cases, individual principals pursue their own parallel channels of influence. The implication for the principal-agent model is that it needs to pay attention to rivalry and bureaucratic politics post-delegation. While bureaucratic politics is well developed in the literature on political science and international relations (Downs 1964; Allison 1971; Halperin 1974; Peters 1992; Christiansen 1997), only a few scholars in the field of the CFSP relate to it when discussing the EEAS and its predecessors (Dijkstra 2009, 2011; Bengtsson and Allen 2011; Adler-Nissen 2014). From the overview above, it is clear that the EU Delegations and previously the Commission Delegations have been keen to avoid blatant rivalry by trying not to antagonise national embassies. Yet bureaucratic politics is not something one can fully avoid. It is always under the surface.

To understand the governance of the CFSP and the non-exclusive delegation to the EEAS and its EU Delegations, one therefore needs to take the role of the individual members of a collective principal more seriously than is typically done in principal-agent models. The power games in delegation decisions are real. While individual member states might (have to) accept delegation as part of a collective principal, they will actively seek to work against it post-delegation. Their own bilateral channels with external parties are an important means. It is important to recognise, in this respect, that the EEAS and its EU Delegations were not about a one-shot delegation game, but that it is about various principal-agent instances at different levels. 


\section{Conclusion}

The principal-agent model is largely about division of labour and specialisation. The principals tend to delegate when they expect higher pay-offs in case an agent carries out certain functions. This is the functional logic which is fundamental to many of the principal-agent model across disciplines. It has long been recognised that bringing such functional models into the study of political science is not without problems (Moe 1984, 1990). And most scholars would point at the importance of power in the relations between principals and agents. This chapter has made a case for taking the role of the preferences of the multiple principals seriously when using principal-agent models. Individual principals do not always fully benefit from a delegation contract in all possible instances and may challenge the agent through unilateral means.

The subject of inquiry has been the CFSP. It is a good case, because particularly in the field of external representation, the functional division of labour seems absent. The member states have empowered the EEAS and its EU Delegations, and yet they have continued conducting their own foreign policies. Such instances of non-exclusive delegation question the central assumptions of the principal-agent model. They question the rationale for delegation. They question the hierarchical relationship between principals and agents. And they question whether agents are, in fact, capable of building up information surpluses. In consequence, instances of non-exclusive delegation do not only question whether the principal-agent model provides any explanatory value, but indeed also whether it can be employed in the first place.

The answer to the challenge of non-exclusive delegation this chapter has argued is in the role and behaviour of the individual member states. While individual principals are often written out of the equation due to the assumption of a collective principal (and an excessive interest of most rationalist scholars in formal rules), there is a clear need to understand how they contest the agent in the post-delegation environment, including through non-exclusive delegation. Furthermore, as the empirical case has shown, the establishment of the EEAS and the EU Delegations was the result of a number of different delegation decisions, each of which had their own principal-agent dynamics and each of which was related to incomplete contracting and institutional uncertainty.

A question that needs to be raised is whether non-exclusive delegation in the case of the EEAS and its EU Delegation marks a transitional 
period or is of a more permanent nature. This is important, as in logical terms cases of non-exclusive delegation are difficult to square with the assumptions of the principal-agent model. An argument can be made for both. We have certainly seen a transitional period in which roles needed to be defined and clarified. Typically once a modus vivendi is found, actors adjust their expectations and informally accept a certain division of labour. That having said, there is also a strong degree of persistence. Tensions in major world capitals are likely to continue between EU Delegations and the national embassies about who speaks for the EU and Europe. The problem of non-exclusive delegation is therefore more fundamental than simply a transitional phase.

While instances of non-exclusive delegation are particularly prominent with respect to EU external representation-where the presence of external parties allows for rival bilateral relations - there is no reason to assume that these instances are restricted to this particular domain. The role of individual member states and the problem of incomplete contracting are by no means specific to the field of EU foreign policy.

\section{Notes}

1. It is important that non-exclusive delegation differs from shared competences in the EU. In the case of shared competences, member states can act unilaterally as long as no EU-level policy is adopted. Once EU-level policy is adopted, however, such policies take precedence over national initiatives.

2. The High Representative and the EEAS are formally separate legal entities. The EEAS 'shall support' the High Representative (Council Decision 2010: article 2(1); 'shall be assisted' according to article 27(3) TEU), but also the President of the European Council and the Commission (ibid.: article 2(2)). Undoubtedly, there is some friction between the cabinet of the High Representative and the EEAS, particularly following a change of guard, and this relation might be subject to a principal-agent analysis by itself (see also Graham 2014; Gastinger this volume; Laloux this volume on 'collective agents'). In this chapter, however, any mention of the EEAS includes the High Representative.

3. This chapter distinguishes between 'delegation' (as in an act of delegation, verb) and 'Delegation' (as in a EU Delegation [EU embassy], EU Delegations or Delegations).

4. The horizontal relations with the European Commission and the European Parliament's say over budgetary and personnel matters 
complicate things (Furness 2013). Yet empirical cases are never perfect and principal-agent relations are far clearer in the case of the EEAS than with many other EU institutions.

5. For a more detailed (and sceptical) approach to the one-voice argument, see contributions to Conceição-Heldt and Meunier (2014).

6. I have argued elsewhere that principals may unilaterally make administrative capacity available to control the agent (Dijkstra 2015). These so-called shadow bureaucracies are essentially redundant and operate in parallel to the agent. Since shadow bureaucracies are part of the control mechanisms of the principal, they can be studied through the standard principal-agent model. The problem of non-exclusive delegation is, however, different. It hardly makes empirical sense to argue, for example, that the UK or French embassy in Washington, DC is solely a mechanism to control the EU Delegation. A handful of diplomats in those bilateral embassies may well keep an eye on EU coordination. But the purpose of the embassy as such is clearly not to exclusively control the EU Delegation.

7. See Waterman and Meier (1998) on the use of the principal-agent model in the absence of an informational asymmetry. Delreux and Adriaensen (this volume) are right to treat informational asymmetries as a variable, but this does not mean that principal-agent models are still useful in the complete absence of such asymmetries.

8. The various publications provide conflicting historical dates. This seems partially a result over confusion about the distinction between 'Offices' and 'Delegations'.

9. There is an implicit bias in this chapter towards the larger member states. Indeed, many smaller member states have a much smaller bilateral presence across the globe.

10. A fourth level of delegation decisions takes place on a day-to-day basis: Should the EU Delegation in country X issue a statement on $\mathrm{Y}$ or organise an event on $\mathrm{Z}$ ?

\section{REFERENCES}

Adler-Nissen, R. (2014). Symbolic power in European diplomacy: The struggle between national foreign services and the EU's external action service. Review of International Studies, 40(4), 657-681.

Adriaensen, J. (2016). National administrations in EU trade policy: Maintaining the capacity to control. London: Palgrave Macmillan.

Allison, G. (1971). Essence of decision: Explaining the Cuban Missile Crisis. New York: Longman. 
Austermann, F. (2012). Towards one voice in Beijing? The role of the EU's diplomatic representation in China over time. Journal of European Integration History, 18(1), 83-102.

Austermann, F. (2014). European Union delegations in EU foreign policy: A diplomatic service of different speeds. Basingstoke: Palgrave Macmillan.

Austermann, F. (2015). Representing the EU in China: European Bilateral Diplomacy in a competitive diplomatic environment. In D. Spence \& J. Batora (Eds.), The European external action service: European diplomacy PostWestphalia. Basingstoke: Palgrave Macmillan.

Balfour, R., \& Raik, K. (2013a). Equipping the European Union for the 21st century: National diplomacies, the European external action service and the making of EU foreign policy. Finnish Institute of International Affairs: Helsinki.

Balfour, R., \& Raik, K. (Eds.). (2013b), The European external action service and national diplomacies (EPC Issue Paper 73). Brussels: European Policy Centre.

Beach, D. (2005). The dynamics of European integration: How and when EU institutions matter. Basingstoke: Palgrave Macmillan.

Bengtsson, R., \& Allen, D. (2011). Exploring a triangular drama: The high representative, the council presidency and the commission. In G. MüllerBrandeck-Bocquet \& C. Rüger (Eds.), The high representative for the EU foreign and security policy-review and prospects (pp. 109-129). Baden-Baden: Nomos.

Bergmann, J., \& Niemann, A. (2015). Mediating international conflicts: The European Union as an effective peacemaker? Journal of Common Market Studies, 53(5), 957-975.

Bruter, M. (1999). Diplomacy without a state: The external delegations of the European Commission. Journal of European Public Policy, 6(2), 183-205.

Carta, C. (2012). The European Union diplomatic service: Ideas, preferences and identities. London: Routledge.

Christiansen, T. (1997). Tensions of European governance: Politicized bureaucracy and multiple accountability in the European Commission. Journal of European Public Policy, 4(1), 73-90.

Conceição-Heldt, E., \& Meunier, S. (Eds.). (2014). Speaking with a single voice: The EU as an effective actor in global governance? Journal of European Public Policy, 21(7), 961-979.

Delreux, T., \& Adriaensen, J. (2017). Introduction. Use and limitations of the principal-agent model in studying the European Union. In T. Delreux \& J. Adriaensen (Eds.), The principal-agent model and the European Union (pp. 1-34). London: Palgrave MacMillan.

Dijkstra, H. (2009). Commission versus Council Secretariat: An analysis of bureaucratic rivalry in European foreign policy. European Foreign Affairs Review, 14(3), 431-450. 
Dijkstra, H. (2010). Explaining variation in the role of the EU council secretariat in first and second pillar policy-making. Journal of European Public Policy, $17(4), 527-544$.

Dijkstra, H. (2011). EU external representation in conflict resolution: When does the presidency or the high representative speak for Europe? European Integration Online Papers (EIoP), 15(1), 1-23.

Dijkstra, H. (2013). Policy-making in EU security and defense: An institutional perspective. Basingstoke: Palgrave Macmillan.

Dijkstra, H. (2015). Shadow bureaucracies and the unilateral control of international secretariats: Insights from UN peacekeeping. The Review of International Organizations, $10(1), 23-41$.

Dijkstra, H. (2016). International organizations and military affairs. London: Routledge.

Downs, A. (1964). Inside bureaucracy. Santa Monica: RAND Cooperation.

Dreher, A., \& Jensen, N. (2007). Independent actor or agent? An empirical analysis of the impact of US interests on International Monetary Fund conditions. Journal of Law and Economics, 50(1), 105-124.

Drieskens, E. (2012). What's in a name? Challenges to the creation of EU delegations. The Hague Journal of Diplomacy, 7(1), 51-64.

Dür, A., \& Elsig, M. (2011). Principals, agents, and the European Union's foreign economic policies. Journal of European Public Policy, 18(3), 323-338.

European Commission. (2004). Taking Europe to the world: 50 years of the European commission's external service. Luxembourg: Office for Official Publications of the European Communities.

Franchino, F. (2007). The powers of the union: Delegation in the EU. Cambridge: Cambridge University Press.

Furness, M. (2013). Who controls the European external action service? Agent autonomy in EU external policy. European Foreign Affairs Review, 18(1), $103-125$.

Gastinger, M. (2017). Effects of contestation within a collective agent in EU trade policy-making. In T. Delreux \& J. Adriaensen (Eds.), The principal-agent model and the European Union (pp. 181-202). London: Palgrave MacMillan.

Ginsberg, R. (1989). Foreign policy actions of the European Community: The politics of scale. Lynne Rienner: Boulder.

Graham, E. (2014). International organizations as collective agents: Fragmentation and the limits of principal control at the World Health Organization. European Journal of International Relations, 20(2), 366-390.

Gutner, T. (2005). Explaining the gaps between mandate and performance: Agency theory and World Bank Environmental Reform. Global Environmental Politics, 5(2), 10-37. 
Halperin, M. (1974). Bureaucratic politics and foreign policy. Washington, DC: The Brookings Institution.

Hawkins, D. G., Lake, D. A., Nielson, D. L., \& Tierney, M. J. (Eds.). (2006). Delegation and agency in international organizations. Cambridge University Press.

Helwig, N. (2017). Agent interaction as a source of discretion for the EU high representative. In T. Delreux \& J. Adriaensen (Eds.), The principal-agent model and the European Union (pp. 105-129). London: Palgrave MacMillan.

Henökl, T. (2014). The European external action service: Torn apart between several principals or acting as a smart 'Double-agent'? Journal of Contemporary European Research, 10(4), 382-401.

Holbrooke, R. (1998). To end a war. New York: Random House.

Jupille, J., \& Caporaso, J. (1998). States, agency, and rules: The European Union in global environmental politics. In C. Rhodes (Ed.), The European Union in the world community (pp. 213-229). Lynne Rienner: Boulder.

Kassim, H., \& Menon, A. (2003). The principal-agent approach and the study of the European Union: Promise unfulfilled? Journal of European Public Policy, 10(1), 121-139.

Kostanyan, H. (2014a). The Rationales behind the European external action service: The principal-agent model and power delegation. Journal of Contemporary European Research, 10(2), 167-183.

Kostanyan, H. (2014b). Examining the discretion of the EEAS: What power to act in the EU-Moldova Association Agreement? European Foreign Affairs Review, 19(3), 373-392.

Kostanyan, H., \& Orbie, J. (2013). The EEAS' discretionary power within the Eastern Partnership: In search of the highest possible denominator. Southeast European and Black Sea Studies, 13(1), 47-65.

Laatikainen, K. (2015). The EU delegation in New York: A debut in high political drama. In D. Spence \& J. Batora (Eds.), The European external action service: European diplomacy Post-Westphalia. Basingstoke: Palgrave Macmillan.

Laloux, T. (2017). Designing a collective agent for trilogues in the European Parliament. In T. Delreux \& J. Adriaensen (Eds.), The principal-agent model and the European Union (pp. 83-103). London: Palgrave MacMillan.

Lynn, M., Nielson, D., \& Tierney, M. (2006). A problem of principals: Common agency and social lending at the multilateral development banks. In D. Hawkins, D. Lake, D. Nielson, \& M. Tierney (Eds.), Delegation and Agency in International Organizations (pp. 41-76). Cambridge: Cambridge University Press.

Maurer, H. (2015). Europe in America: An upgraded EU delegation in a reinforced system of European diplomatic coordination. In D. Spence \& J. Batora (Eds.), The European external action service: European diplomacy PostWestphalia. Basingstoke: Palgrave Macmillan. 
Moe, T. (1984). The new economics of organization. American Journal of Political Science, 28(4), 739-777.

Moe, T. (1990). Political institutions: The neglected side of the story. Journal of Law Economics and Organization, 6, 213-253.

Moravcsik, A. (1998). The choice for Europe: Social purpose and state power from Messina to Maastricht. Ithaca: Cornell University Press.

Ministers of Foreign Affairs of Denmark, Finland, Iceland, Norway and Sweden. (2014). Nordic foreign and security policy cooperation: Building security in a comprehensive manner. Retrieved February 12, from http://formin.finland. fi/public $/$ default .aspx ? contentid $=298606 \&$ contentlan $=2 \&$ culture $=$ en-US (consulted April 2016).

Nielson, D., \& Tierney, M. (2003). Delegation to International Organizations: Agency Theory and World Bank Environmental Reform. International Organization, 57(2), 247-249.

Nuttall, S. (2000). European foreign policy. Oxford: Oxford University Press.

Oatley, T., \& Yackee, J. (2004). American interests and IMF lending. International Politics, 41(3), 415-429.

Peters, G. (1992). Bureaucratic politics and the institutions of the European Community. In A. Sbragia (Ed.), Euro-politics: Institutions and policymaking in the new European Community. Washington, DC: Brookings Institution Press.

Pollack, M. (1997). Delegation, agency, and agenda setting in the European Community. International Organization, 51(1), 99-134.

Pollack, M. (2003). The engines of European integration: Delegation, agency, and agenda setting in the EU. Oxford: Oxford University Press.

Puetter, U. (2014). The European council and the council. New intergovernmentalism and institutional change. Oxford: Oxford University Press.

Rena, K. (2013). The contemporary embassy: Paths to diplomatic excellence. Basingstoke: Palgrave Macmillan.

Rittberger, B. (2005). Building Europe's parliament: Democratic representation beyond the nation state. Oxford: Oxford University Press.

Sobol, M. (2016). Principal-Agent analysis and pathological delegation: The (almost) untold story. Governance, 29(3), 335-350.

Spence, D. (2004). The European commission's external service. Public Policy and Administration, 19(3), 61-76.

Spence, D. (2015). From the convention to Lisbon: External competence and the uneasy transition for Geneva delegations. In D. Spence \& J. Batora (Eds.), The European external action service: European diplomacy PostWestphalia. Basingstoke: Palgrave Macmillan.

Spence, D., \& Batora, J. (Eds.). (2015). The European external action service: European diplomacy Post-Westphalia. Basingstoke: Palgrave Macmillan.

Stone, R. (2004). The political economy of IMF lending in Africa. American Political Science Review, 98(4), 577-591. 
Stone, R. (2008). The scope of IMF conditionality. International Organization, $62(4), 589-620$.

Stone, R. (2011). Controlling institutions: International organizations and the global economy. Cambridge: Cambridge University Press.

Tallberg, J. (2002). Delegation to supranational institutions: Why, how, and with what consequences? West European Politics, 25(1), 23-46.

Tallberg, J. (2006). Leadership and negotiation in the European Union. Cambridge: Cambridge University Press.

Thacker, S. (1999). The high politics of IMF lending. World Politics, 52(1), 38-75.

Thompson, A. (2007, April 12-15). Principal problems: UN weapons inspections in Iraq and beyond. Paper presented at Annual National Conference of the Midwest Political Science Association, Chicago.

UK House of Lords. (2013, March 19). The EU's external action service. HL Paper 147.

Waterman, R., \& Meier, K. (1998). Principal-Agent models: An expansion? Journal of Public Administration Research and Theory, 8(2), 173-202.

\section{Author Biography}

Hylke Dijkstra is an Assistant Professor (with tenure) at the Department of Political Science, Maastricht University. He is also the Editor-in-Chief of Contemporary Security Policy. He has widely published on the EU, the UN and NATO from a principal-agent perspective. He is the author of International Organizations and Military Affairs (Routledge 2016) and Policy-Making in EU Security and Defense: An Institutional Perspective (Palgrave 2013). 